\title{
Involvement of vascular endothelial growth factor signaling in CLR/RAMP1 and CLR/RAMP2-mediated pro-angiogenic effect of intermedin on human vascular endothelial cells
}

\author{
GIOVANNA ALBERTIN, ELISA SORATO, BARBARA OSELLADORE, ALESSANDRA MASCARIN, \\ CINZIA TORTORELLA and DIEGO GUIDOLIN \\ Department of Human Anatomy and Physiology, Section of Anatomy, \\ University of Padova-Medical School, I-35121 Padova, Italy
}

Received January 27, 2010; Accepted March 30, 2010

DOI: 10.3892/ijmm_00000464

\begin{abstract}
Intermedin (IMD) is a recently discovered peptide closely related to adrenomedullin. Its principal physiological activity is its role in the regulation of the cardiovascular system, where it exerts a potent hypotensive effect. In addition, data were recently provided showing that this peptide is able to exert a clearcut pro-angiogenic effect both in vitro and in vivo. IMD acts through the non-selective interaction with receptor complexes formed by the dimerization of calcitoninlike receptor (CLR) with the receptor activity-modifying proteins RAMP1, 2 or 3 . Thus, in the present study, the role of CLR/RAMP complexes in mediating the pro-angiogenic effect induced by IMD on human umbilical vein endothelial cells (HUVECs) cultured on Matrigel was examined. Real-time PCR demonstrated the expression of IMD, CLR/RAMP1 and CLR/RAMP2 (but not CLR/RAMP3) mRNA in HUVECs. IMD exerted a significant in vitro angiogenic action, specifically triggered by the binding of the peptide to CLR/RAMP complexes. Both CLR/RAMP1 and CLR/RAMP2 appeared to mediate the pro-angiogenic effect, which was associated with a significant increase of vascular endothelial growth factor (VEGF) mRNA expression $18 \mathrm{~h}$ following IMD administration, indicating that the observed pro-angiogenic effects are related, at least in part, to an increased synthesis of this growth factor promoted by the peptide. Western blot analysis, however, showed a significant increase of VEGF receptor-2 phosphorylation as early as 5 min following IMD administration, indicating that IMD induces a pro-angiogenic response in human vascular endothelial cells not only via CLR/RAMP-induced release of VEGF, but also during signal
\end{abstract}

Correspondence to: Dr Diego Guidolin, Department of Human Anatomy and Physiology, Section of Anatomy, Via Gabelli 65, I-35121 Padova, Italy

E-mail: diego.guidolin@unipd.it

Key words: intermedin, calcitonin-like receptor/RAMP, angiogenesis, vascular endothelial growth factor, transactivation initiation and propagation by transactivating the VEGF receptor-2 machinery.

\section{Introduction}

In early 2004, a novel member of the calcitonin (CT)/calcitoningene related peptide (CGRP) family was independently identified by two separate groups. Roh and colleagues (1) discovered the human form of this peptide in cells within the intermediate lobe of the pituitary and called it intermedin (IMD). At the same time, Takei et al (2) identified in mammals a 146150 amino acid prepro-hormone which yielded to a 47 -amino acid mature peptide with $33 \%$ sequence homology to adrenomedullin (AM) and $71 \%$ homology to the puffer fish AM orthologue AM2. Thus, they called it mammalian AM2. Confirmation that the sequences of human prepro-AM2 and -IMD (148 amino acids each) were identical and that the mature peptides induced similar biological actions, led to general acceptance that IMD and AM2 were the same peptide (reviewed in ref. 3).

In mammals, IMD is expressed not only in the central nervous system (CNS) but also in peripheral tissues such as heart, kidney, lung, gastrointestinal tract and thymus $(1,2,4,5)$. IMD has been quantified in plasma of rat and human (3), but the origin of the peptide in plasma is unclear. The pituitary is likely to make a significant contribution but, recently, human aortic endothelial cells (ECs) were also shown to express IMD mRNA and secrete the peptide (6).

As with other members of its peptide family, the principal physiological activity of IMD is its role in the regulation of the cardiovascular system. Following intravenous or intraperitoneal administration in rodents, the peptide exerts a potent hypotensive effect with a decrease in arterial pressure and increase in heart rate $(7,8)$. However, when IMD was administered intracerebroventricularly $(4,9)$ or injected into the nucleus tractus solitarius (10), it showed inverse effects on the regulation of arterial pressure, suggesting that distinct regulatory mechanisms are triggered by the peptide in the CNS and periphery.

In addition to the mentioned role in the control of cardiovascular function, recently, data were provided showing that IMD has antiapoptotic activity in human ECs (6) and, like other members of its peptide family, such as CGRP $(11,12)$ and, in 
particular, AM (13-15), is able to exert a clearcut pro-angiogenic effect both in vitro and in vivo (16).

It is well known (17) that the peptides of the CGRP family rely on calcitonin-like receptor (CLR), a G protein-coupled receptor (GPCR), as the main structural component of their membrane receptor. The specificity is provided by the dimerization of CLR with one of the three proteins forming the group of the receptor activity-modifying proteins (RAMP). Thus, CLR associated with RAMP1 is a CGRP-specific receptor, while the coupling of CLR with RAMP2 or 3 leads to the AM-specific receptors AM1 or 2, respectively. In contrast to CGRP and AM, IMD interacts non-selectively with any CLR accompanied by RAMP1, 2 or $3(1,2)$.

Thus, in the present study, we examined in more detail the role played by different CLR/RAMP complexes in mediating the pro-angiogenic effect induced by IMD on human vascular ECs cultured on Matrigel (18), a reliable in vitro assay to identify substances with potential anti- or pro-angiogenic properties (19). Furthermore, since in this experimental model the pro-angiogenic response of human ECs induced by the binding of the peptide AM to the CLR/RAMP2 receptor complex was recently suggested (15) to involve transactivation of the VEGF receptor 2 (VEGFR-2), we focused on the potential relationship between IMD stimulation of CLR/RAMP complexes and VEGF signaling.

\section{Materials and methods}

Reagents. Human IMD, AM, CGRP, $\mathrm{AM}_{22-52}$ and $\mathrm{CGRP}_{8-37}$ were purchased from Phoenix Pharmaceuticals (Burlingame, CA) and FGF-2 from Preprotech (London, UK). Matrigel was obtained from Becton-Dickinson Labware (Bedford, MA) and Lipofectamine $^{\mathrm{TM}} 2000$ Transfection Reagent from Invitrogen Srl (Milan, Italy). CLR siRNA (sc-43705) was purchased from Santa Cruz Biotechnology (Santa Cruz, CA). Antibodies to phosphotyrosines, human VEGFR-2 and GAPDH were from Millipore (Milan, Italy). EC basal medium (EBM), fetal calf serum (FCS), bovine serum albumin (BSA), phosphate buffered saline (PBS) and all other chemicals and reagents were provided by Sigma-Aldrich Corp. (St. Louis, MO).

Cell cultures. Human umbilical vein endothelial cells (HUVECs) were obtained from samples of the umbilical cord. Informed consent was obtained from all patients and all the procedures were approved by the local ethics committee. After resection, the specimens were immediately placed into EC basal medium (EBM) and repeatedly rinsed with PBS and antibiotics. Remaining impurities, such as adherent blood cells, were then carefully removed. After rinsing, the umbilical cord was clamped and placed in a culture plate with $0.1 \%$ type II collagenase at $37^{\circ} \mathrm{C}$. After 15 min digested tissue was collected and the cell suspension was centrifuged at 2,000 rpm for $5 \mathrm{~min}$. The pellet was then re-suspended in fresh EBM supplemented with $10 \%$ fetal bovine serum, $100 \mathrm{IU} / \mathrm{ml}$ penicillin and $100 \mathrm{mg} / \mathrm{l}$ streptomycin and plated onto a fibronectin-precoated culture dish $\left(1 \mu \mathrm{g} / \mathrm{cm}^{2}\right)$ at $37^{\circ} \mathrm{C}$ in a humidified incubator $\left(5 \% \mathrm{CO}_{2}\right.$, $95 \%$ air). When cultures were grown to near-confluence, cells were detached, harvested and incubated for $30 \mathrm{~min}$ at $4^{\circ} \mathrm{C}$ with Tosylactivated Dynabeads M-450 (Oxoid Italy, Milan, Italy) coated with anti-human CD31 antibodies in order to separate EC by magnetic immunoseparation (20). The endothelial phenotype of isolated cells was confirmed by flow cytometry and immunocytochemistry, using anti-von Willebrand factor antibody, as previously described (21). In all experiments, cultures of HUVECs from the 3rd to 6th passage were used.

Real-time PCR. To detect the expression of mRNA for IMD, CLR, RAMP1, 2, 3, VEGF, VEGFR-1, -2 and the changes they underwent in the different experimental conditions applied, HUVECs were harvested and total RNA was extracted with the SV Total RNA Isolation System (Promega Corporation, Madison, WI) and purified. During RNA extraction a DNase treatment was also carried out to remove genomic DNA contamination. Total RNA was then reverse transcribed to cDNA (22). Real-time PCR (RT-PCR) was carried out in an I-Cycler iQ detection system (BioRad Laboratories, Milan, Italy), using the primers reported in Table I. The PCR program included a denaturation step at $95^{\circ} \mathrm{C}$ for $3 \mathrm{~min}, 40$ cycles of two amplification steps $\left(95^{\circ} \mathrm{C}\right.$ for $10 \mathrm{sec}$ and annealing extension at $60^{\circ} \mathrm{C}$ for $\left.20 \mathrm{sec}\right)$ and a melting curve $\left(60-90^{\circ} \mathrm{C}\right.$ with a heating rate of $0.5^{\circ} \mathrm{C} / 10 \mathrm{sec}$ ) as detailed previously (23). To detect the gene expression of IMD the same protocol was applied with the exception for melting. The analysis was carried out with a UPL probe (Roche Diagnostic, Mannheim, Germany). During the exponential phase, the fluorescence signal threshold was calculated and the fraction number of PCR cycles required to reach the threshold (cycle threshold, $\mathrm{Ct}$ ) was determined. Ct values decreased linearly with increasing input target quantity and were used to calculate the relative mRNA expression, according to the mathematical quantification model proposed by Pfaffl (24). Following this method, the IMD-induced variation in mRNA expression with respect to unstimulated control samples was estimated by calculating for each analysed gene a parameter, indicating the relative gene expression (25). When up- or down-regulation of the gene occured as an effect of the applied stimulus, this parameter was significantly greater or lower than 1.0, respectively. All samples were amplified in duplicate and glyceraldehyde 3-phosphate dehydrogenase (GAPDH) expression was used as a reference to normalize the data.

Western blotting. Activation of VEGFR-2 in response to VEGF (50 ng/ml), IMD (10 $\left.10^{-6} \mathrm{M}\right)$, AM $\left(10^{-8} \mathrm{M}\right)$ and CGRP $\left(10^{-6} \mathrm{M}\right)$ stimulation was examined by Western blotting as detailed elsewhere (15). Briefly, 5 min following stimulation, cells were lysed with Lysis Buffer (0.6\% TritonX-100; $0.15 \mathrm{M} \mathrm{NaCl}$; $10 \mathrm{mM}$ Tris pH 7.4; 1 mM EDTA) plus protease and phosphatase inhibitors and homogenized. Cell extracts were Western blotted and probed with monoclonal antibodies to phospho-proteins. Molecular weights were estimated by comparison to prestained molecular mass marker proteins (Bio-Rad Laboratories, Milan, Italy).

Blots were then reprobed for total receptor using antiVEGFR-2 antibodies. A mouse anti-human GAPDH protein antibody was used as a control for equal loading. The relative levels of active and total protein were quantified by image analysis using ImageJ software (National Institutes of Health, Bethesda, MD) and densitometric data were expressed as the ratio between active and total protein. 
Table I. Sense and antisense sequences used as RT-PCR primers.

\begin{tabular}{|c|c|c|c|}
\hline & Accession no. & Primers & $\mathrm{bp}$ \\
\hline \multirow[t]{2}{*}{ GAPDH } & NM_002046.3 & $\begin{array}{l}\text { 5'-CTC-TCT-GCT-CCT- } \\
\text { CCT-GTT-CGA-C-3' }\end{array}$ & \\
\hline & & $\begin{array}{l}\text { 5'-TGA-GCG-ATG-TGG- } \\
\text { CTC-GGC-T-3' }\end{array}$ & 69 \\
\hline \multirow[t]{2}{*}{ IMD } & NM_024866 & $\begin{array}{l}\text { 5'-GCC-AGG-TGC-AGA- } \\
\text { ATC-TCA-G-3' }\end{array}$ & \\
\hline & & $\begin{array}{l}\text { 5'-ATA-GCT-GTG-GGG- } \\
\text { GCT-GCT-3' }\end{array}$ & 98 \\
\hline \multirow[t]{2}{*}{ CLR } & XM_043055 & $\begin{array}{l}\text { 5'-AGA-AGG-CGT-TTA- } \\
\text { CTG-CAA-CAG-3' }\end{array}$ & \\
\hline & & $\begin{array}{l}\text { 5'-TCC-CTG-TCC-AAT- } \\
\text { TAT-GGT-CAG-3' }\end{array}$ & 271 \\
\hline \multirow[t]{2}{*}{ RAMP1 } & NM_005855 & $\begin{array}{l}\text { 5'-CAG-GAC-CAT-CAG- } \\
\text { GAG-CTA-CA-3' }\end{array}$ & \\
\hline & & $\begin{array}{l}\text { 5'-CCT-ACA-CAA-TGC- } \\
\text { CCT-CAG-TG- 3' }\end{array}$ & 269 \\
\hline \multirow[t]{2}{*}{ RAMP2 } & NM_005854.1 & $\begin{array}{l}\text { 5'-CTG-CTG-GGC-GCT- } \\
\text { GTC-CTG-AA-3' }\end{array}$ & \\
\hline & & $\begin{array}{l}\text { 3'-TTC-TGA-CCC-TGG- } \\
\text { TGT-GCC-TGT-G-3' }\end{array}$ & 75 \\
\hline \multirow[t]{2}{*}{ RAMP3 } & NM_005856 & $\begin{array}{l}\text { 5'-AAC-TTC-TCC-CGT- } \\
\text { TGC-TGC-TGC-T-3' }\end{array}$ & \\
\hline & & $\begin{array}{l}\text { 5'-ACA-GGT-TGC-ACC- } \\
\text { ACT-TCC-AGA-CG-3' }\end{array}$ & 150 \\
\hline \multirow[t]{2}{*}{ VEGF } & NM_001025368 & $\begin{array}{l}\text { 5'-GCC-TTG-CTG-CTC- } \\
\text { TAC-CTC-CAC-3' }\end{array}$ & \\
\hline & & $\begin{array}{l}\text { 5'-GAT-TCT-GCC-CTC- } \\
\text { CTC-CTT-CTG-C-3' }\end{array}$ & 73 \\
\hline \multirow[t]{2}{*}{ VEGFR-1 } & NM_002019 & $\begin{array}{l}\text { 5'-GTT-CAA-GGA-ACC- } \\
\text { TCG-GAC-AA-3' }\end{array}$ & \\
\hline & & $\begin{array}{l}\text { 5'-GCT-CAC-ACT-GCT- } \\
\text { CAT-CCA-AA-3' }\end{array}$ & 192 \\
\hline \multirow[t]{2}{*}{ VEGFR-2 } & NM_002253.1 & $\begin{array}{l}\text { 5'-GTT-CTT-GGC-TGT- } \\
\text { GCA-AAA-GT-3' }\end{array}$ & \\
\hline & & $\begin{array}{l}\text { 5'-GTC-TTC-AGT-TCC- } \\
\text { CCT-CCA-TT-3' }\end{array}$ & 43 \\
\hline
\end{tabular}

Each analyzed gene is reported together with the accession number identifying it in the NCBI Nucleotide data bank.

In vitro angiogenesis assay. Growth factor-depleted Matrigel was thawed on ice overnight, and spread evenly over each well $(50 \mu 1)$ of a 24-well plate. Plates were incubated for $30 \mathrm{~min}$ at $37^{\circ} \mathrm{C}$ to allow Matrigel to gel, and HUVECs were seeded $\left(2.5 \times 10^{4}\right.$ cells/well $)$ and cultured in basal medium, containing $50 \mathrm{ng} / \mathrm{ml} \mathrm{FGF-2} \mathrm{(positive} \mathrm{control)} \mathrm{or} \mathrm{AM} \mathrm{(positive} \mathrm{control)} \mathrm{or}$ supplemented with IMD $\left(10^{-12}-10^{-6} \mathrm{M}\right)$. After $18 \mathrm{~h}$ of incubation at $37^{\circ} \mathrm{C}$, cultures were observed under the microscope at a primary magnification of $x 5$. Phase contrast images were recorded ( 5 fields for each well, four quadrants and center) and saved as Tiff files. Image analysis of the cell pattern was carried out using the QWin image analysis software, as previously detailed (26), and the following parameters were estimated, percent area covered by HUVECs, total length of HUVEC network per field, and number of meshes and branching points per field. Values were expressed as percent of the control value.

Gene silencing. CLR depletion was obtained by transfecting cells with CLR siRNA. siRNAs, added at a concentration of $15 \mathrm{nM}$, were administered into cells using the lipid-based agent Lipofectamine 2000 Transfection Reagent. The formed transfection complexes were incubated for $20 \mathrm{~min}$ at room temperature and then dispensed into the wells of a culture plate containing cells seeded the day before $\left(5 \times 10^{4}\right.$ cells $\left./ \mathrm{cm}^{2}\right)$. Cells were then incubated under their normal growth conditions. HUVECs were monitored for gene silencing after 24, 48 and $72 \mathrm{~h}$ following transfection by real-time PCR. Cells were then plated and the in vitro angiogenesis assay performed as described above.

IMD antagonism. In vitro angiogenesis assays were also performed by administering IMD in the presence of AM and CGRP receptor antagonists, $\mathrm{AM}_{22-52}$ and $\mathrm{CGRP}_{8-37}$ respectively. $\mathrm{AM}_{22-52}$ is the C-teminal fragment of AM which lacks the cyclic structure but binds the AM receptors acting as an antagonist (27). $\mathrm{CGRP}_{8-37}$ is a selective competitive antagonist of CGRP receptors (28). In our experiments the antagonists were administered at the concentration of $10^{-5} \mathrm{M}$.

VEGFR-2 inhibition. The effect of IMD on in vitro angiogenesis was also tested in the presence of SU5416, a selective inhibitor $\left(\mathrm{IC}_{50}=0.16 \mu \mathrm{M}\right)$ of the tyrosine kinase activity of the VEGFR-2 receptor (29). Thus, it blocks the downstream signaling of the receptor without affecting its affinity for VEGF. It was administered to cells at a concentration of $0.4 \mu \mathrm{M}(15)$.

Statistics. All experiments were carried out at least three times in triplicate and results were expressed as means \pm SEM. Data were analyzed by one-way analysis of variance (ANOVA) followed by Dunnett's test for multiple comparisons versus the control group. The statistical analysis was carried out using GraphPad Prism software (version 3.03; GraphPad Software Inc., San Diego, CA, USA).

\section{Results}

As illustrated in Fig. 1, RT-PCR revealed that the isolated cells exhibited a significant expression of IMD. Moreover, they expressed CGRP and AM1 receptors (as indicated by the presence of CLR, RAMP1 and 2 mRNAs), but not the AM2 receptor, because no RAMP3 mRNA was detected in the cell preparations.

After seeding on Matrigel, HUVECs spread and aligned with each other to form branching anastomosing tubes with multicentric junctions that gave rise within $18 \mathrm{~h}$ to a meshwork of capillary-like structures. FGF-2 $(50 \mathrm{ng} / \mathrm{ml})$ and IMD $\left(10^{-6} \mathrm{M}\right)$ increased the complexity of the meshwork (an example of the obtained cell pattern is shown in Fig. 2B). Image analysis confirmed these observations, showing that IMD, starting from the dose of $10^{-6} \mathrm{M}$, significantly increased both dimensional (percent area covered by HUVECs and total length of the network per field) and topological parameters (number of meshes and branching points per field) of the capillary-like meshwork (Fig. 2A). 


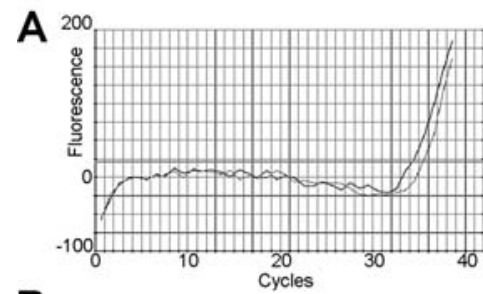

B

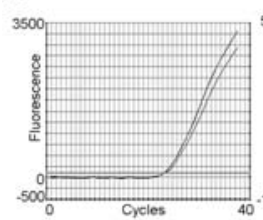

D

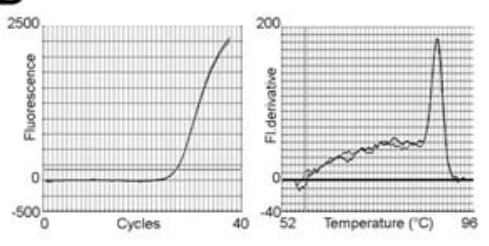

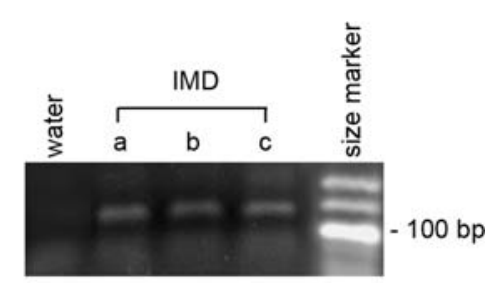

C
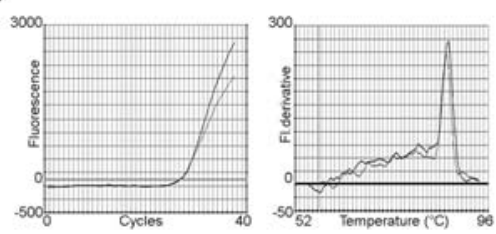

E
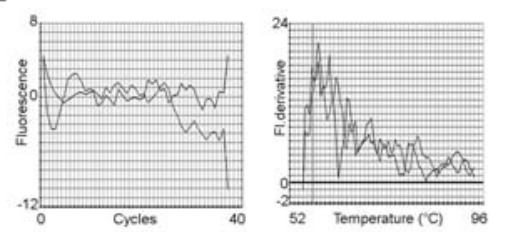

Figure 1. Markers expressed by cultured HUVECs. A. Amplification plot for IMD together with ethidium bromide-stained agarose gel showing cDNA amplified with human IMD specific primers from RNA of three exemplary cultured HUVECs. No amplification with water instead of RNA is shown as negative control. B-D. Amplification plots (left) and melting curves (right) with a specific single peak demonstrating in HUVECs the presence of CLR, RAMP1 and 2 mRNA respectively. E. RT-PCR analysis of RAMP3 mRNA expression in HUVECs, neither amplification nor specific melting curve was obtained, indicating the lack of expression of this marker in the cells.

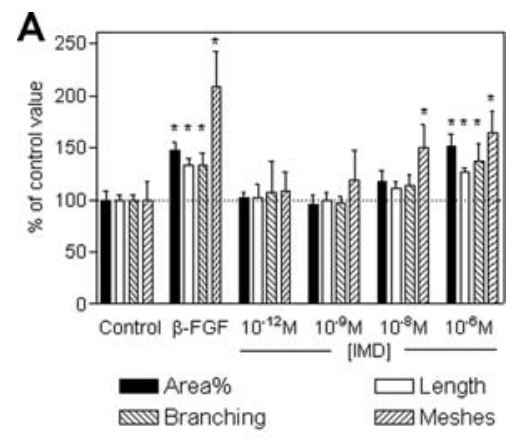

B

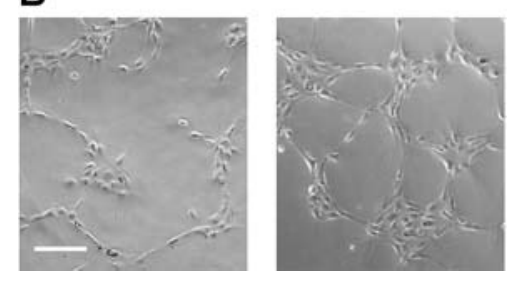

Figure 2. Effect of IMD on the structure of the capillary-like network formed by HUVECs cultured on Matrigel. A. Morphometric analysis of the effect of increasing concentrations of IMD. A significant increase of both dimensional (percent area covered by cells and total length of the meshwork per field) and topological (number of meshes and branching points per field) parameters of the cell pattern was observed from a dose of $10^{-6} \mathrm{M}$ ( ${ }^{*} \mathrm{p}<0.05$ vs. control group). B. Phase contrast micrographs providing an example of the pattern formed by HUVECs at baseline (left) and in the presence of $10^{-6} \mathrm{M}$ IMD (right). Bar, $200 \mu \mathrm{m}$.

As shown in Fig. 3A, when tests were performed using HUVECs where CLR was almost suppressed by gene silencing (the CLR inhibition was $~ 90 \%$ ), the morphogenetic effect of FGF-2 was not altered whereas the IMD effect was no longer detectable, indicating that it was mediated by the binding of IMD to CLR/RAMP complexes. However, when IMD was
A

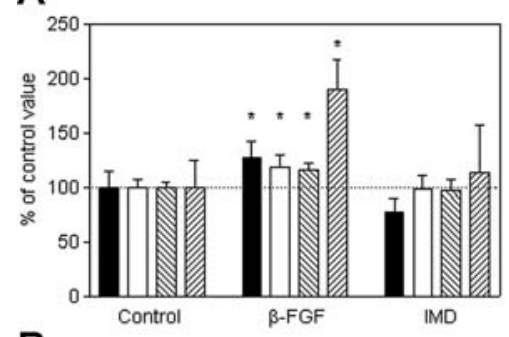

B

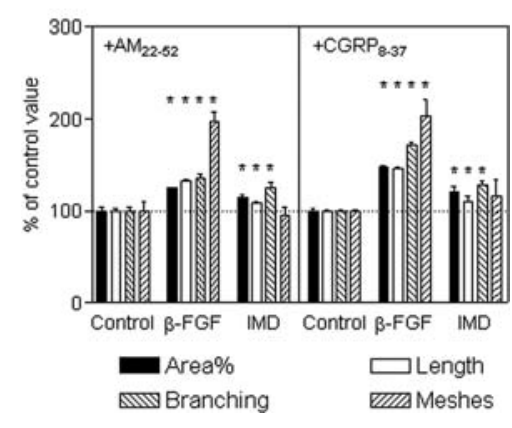

Figure 3. A. Morphometric analysis of the effect of IMD on HUVECs in which the expression of CLR was almost suppressed by gene silencing. In this experimental condition the effect of IMD was no longer detectable, indicating that it was mediated by functional CLR/RAMP complexes. Conversely, the morphogenetic action of $\beta$-FGF was not altered. B. $\operatorname{AM}_{22-52}\left(10^{-5} \mathrm{M}\right)$ or CGRP $_{8-37}\left(10^{-5} \mathrm{M}\right)$, selective inhibitors of CLR/RAMP2 and CLR/RAMP1 respectively, were unable to completely block the pro-angiogenic effect of IMD, suggesting that they are both involved in mediating the effect. ${ }^{*} \mathrm{p}<0.05$ vs. control group.

administered to cells in the presence of $\mathrm{GCRP}_{8-37}$ or $\mathrm{AM}_{22-52}$ (selective antagonists of CLR/RAMP1 and CLR/RAMP2 respectively), neither antagonist was able to completely block the peptide effect (Fig. 3B), indicating that both the receptor 
Table II. Semiquantitative RT-PCR assay of the effect of IMD $\left(10^{-6} \mathrm{M}\right)$ on HUVECs.

\begin{tabular}{cccc}
\hline & VEGF & VEGFR-1 & VEGFR-2 \\
\hline $4 \mathrm{~h}$ & $0.97 \pm 0.05$ & $1.05 \pm 0.10$ & $1.07 \pm 0.12$ \\
& $(\mathrm{p}=0.565)$ & $(\mathrm{p}=0.630)$ & $(\mathrm{p}=0.576)$ \\
$18 \mathrm{~h}$ & $1.54 \pm 0.07$ & $1.87 \pm 0.19$ & $1.74 \pm 0.16$ \\
& $(\mathrm{p}<0.01)$ & $(\mathrm{p}<0.01)$ & $(\mathrm{p}<0.01)$ \\
\hline
\end{tabular}

$\mathrm{p}$, one-sample t-test compared to hypothetical value 1.0; values (mean $\pm \mathrm{SEM}$, $\mathrm{n}=9$ ) represent relative mRNA expression with respect to untreated control samples.

complexes are involved in mediating the pro-angiogenic activity of IMD.

PCR data (Table II) indicate a significant increase of VEGF, VEGFR-1 and -2 mRNA expression after $18 \mathrm{~h}$ of IMD treatment, suggesting that the pro-angiogenic effect of IMD is mediated by an up-regulation of the VEGF system.

As illustrated in Fig. 4A, however, a significant increase of VEGFR-2 phosphorylation is observed as early as $5 \mathrm{~min}$ following $10^{-6} \mathrm{M}$ IMD, $10^{-8} \mathrm{AM}$ or $10^{-6} \mathrm{CGRP}$ administration, indicating that a transactivation of the VEGFR-2 as a consequence of the binding of IMD to CLR/RAMP complexes has to be considered as an additional mechanism associated with the pro-angiogenic effect of the peptide.

Consistent with these findings are the results of in vitro angiogenesis assays when performed in the presence of SU5416, selective inhibitor of the tyrosine kinase activity of the VEGFR-2 (Fig. 4B). As shown, under this condition the effect of IMD was abolished.

\section{Discussion}

Recent data demonstrated that IMD is a novel and potent angiogenic peptide, able to enhance the neovascularization in the rat ischemic hindlimb, leading to a complete restoration of blood flow, and to promote migration and tube formation of cultured endothelial cells (ECs) (16). The data obtained in the present study are consistent with these findings and provide further details on the pro-angiogenic action of the peptide on cultured human ECs, confirming that IMD is included in the group of non-classic pro-angiogenic cytokines expressed in ECs (30), which, in addition to regulating cardiovascular function, also exert a tissue-remodeling action. In fact, IMD appeared to be expressed by HUVECs together with its receptor complexes CLR/RAMP1 and CLR/RAMP2 (but not CLR/RAMP3). As demonstrated by the lack of response observed in HUVECs when CLR expression was inhibited by RNA interference, the pro-angiogenic response in human ECs appeared to be specifically triggered by the binding of the peptide to CLR/RAMP complexes. Moreover, the results of the experiments in which only CLR/RAMP1 or CLR/RAMP2 were antagonized (by using the specific inhibitors $\mathrm{CGRP}_{8-37}$ or $\mathrm{AM}_{22-52}$, respectively) suggest that the two receptors mediated the morphogenetic response in HUVECs, being that the effect of IMD only partially inhibited in this experimental condition. This finding is not surprising, being consistent with previously

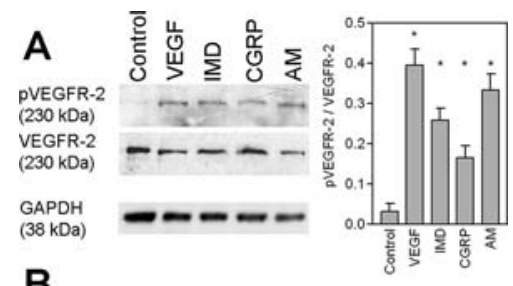

B

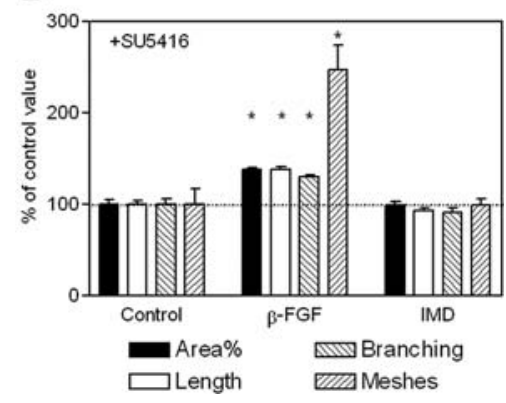

Figure 4. A. Western blot assessment (left panel) of the phosphorylated VEGFR-2 in control HUVECs and in HUVECs treated for 5 min with $50 \mathrm{ng} / \mathrm{ml}$ VEGF (positive control), $10^{-6} \mathrm{M}$ IMD, CGRP $\left(10^{-6} \mathrm{M}\right)$ (12) or AM $\left(10^{-8} \mathrm{M}\right)(15)$. The level of GAPDH was used as a control for loading. Bands were quantitated by densitometry (right panel) and data are expressed as the ratio between phosphorylated and total VEGFR-2. As expected VEGF induced a significant increase of VEGFR-2 phosphorylation. However, a significant increase of activated VEGFR-2 was also observed after 5 min of IMD, CGRP or AM stimulation, respectively $\left({ }^{*} \mathrm{p}<0.05, \mathrm{n}=3\right)$. B. Consistently, in the presence of SU5416, which blocks tyrosine kinase activity of VEGFR-2, the action of IMD on HUVEC self-organization was no longer detectable. As shown, B-FGF was always active in this experimental condition. ${ }^{*} \mathrm{p}<0.05$ vs. control group.

reported data demostrating that both $\operatorname{CGRP}(11,12,31)$, specific ligand of CLR/RAMP1, and AM $(14,15)$, specific ligand of CLR/RAMP2, have a clearcut pro-angiogenic effect on human vascular ECs.

Consistent with the data by Smith et al (16), in the present study the pro-angiogenic effect of IMD was associated with a significant increase in VEGF expression by HUVECs $18 \mathrm{~h}$ following IMD administration. Thus, the pro-angiogenic effects of IMD may be related, at least in part, to an increased synthesis of this growth factor promoted by the peptide.

The most interesting and novel finding of the present study, however, was the observation that the activation of CLR/RAMP receptor complexes by IMD leads to a rapid phosphorylation of the VEGFR-2. The same result was obtained following administration of AM or CGRP, indicating a second mechanism underlying the pro-angiogenic action of this peptide family, namely a VEGFR-2 transactivation triggered by CLR/RAMP1 and CLR/RAMP2 signaling. VGFR-2 belongs to a class of receptor tyrosine kinases (RTK) and over the past decades many examples of transactivation of RTK in response to GPCR signaling have been reported (reviewed in ref. 32). They include, for instance, the receptors for platelet-derived growth factor (PDGF) (33), epidermal growth factor (EGF) (34) and insulin-like growth factor-1 (ILGF-1) (35). As far as VEGFR-2 is concerned, its involvement in response to CLR/RAMP2 signaling was recently suggested as the principal mechanism leading to the AM-induced pro-angiogenic response in human vascular EC (15). The data here presented provide additional evidence to this finding.

Thus, IMD can induce a pro-angiogenic response in human vascular ECs not only via CLR/RAMP-induced release of 
VEGF, but also during signal initiation and propagation by activating the VEGFR-2 machinery. Once transactivated, this receptor provides the structural scaffold for the assembly of signaling complexes resembling those formed when it encounters its endogenous ligand VEGF. As a consequence, the data here presented are also of potential interest for the design of future anti-angiogenic therapeutical protocols, because they indicate that there are alternative modes of activating the VEGF signaling cascade even in the absence of the trophic factor binding at the cell surface.

\section{References}

1. Roh J, Chang CL, Bhalla A, Klein C and Hsu SYT: Intermedin is a calcitonin/CGRP family peptide acting through the calcitonin receptor-like receptor activity modifying protein receptor complexes. J Biol Chem 279: 7264-7274, 2004.

2. Takey Y, Hyodo S, Katafuchi T and Minamino N: Novel fishderived adrenomedullin in mammals: structure and possible function. Peptides 25: 1643-1656, 2004.

3. Bell D and McDermott BJ: Intermedin (adrenomedullin-2): a novel counter-regulatory peptide in the cardiovascular and renal systems. Br J Pharmacol 153: S247-S262, 2008.

4. Taylor MM, Bagley SL and Samson WK: Intermedin/ adrenomedullin-2 inhibits growth hormone release from cultured, primary anterior pituitary cells. Endocrinology 147: 859-864, 2005.

5. Morimoto R, Satoh F, Murakami O, Totsune K, Suzuki T, Sasano H, Ito S and Takahashi K: Expression of adrenomedullin2/ intermedin in human brain, heart and kidney. Peptides 28 : 1095-1103, 2007.

6. Pearson LJ, Yandle TG, Nicholls MG and Evans JJ: Intermedin (Adrenomedullin-2): a potential protective role in human aortic endothelial cells. Cell Physiol Biochem 23: 97-108, 2009.

7. Pan CS, Yang JH, Cai DY, Zhao J, Gerns H, Yang J, Chang JK, Tang CS and Qi YF: Cardiovascular effects of newly discovered peptide intermedin/adrenomedullin 2. Peptides 26: 1640-1646, 2005.

8. Fujisawa Y, Nagai Y, Miyatake A, Miura K, Shokoji T, Nishiyama A, Kimura S and Abe Y: Roles of adrenomedullin 2 in regulating the cardiovascular and sympathetic nervous system in conscious rats. Am J Physiol Heart Circ Physiol 290: H1120-H1127, 2006.

9. Hashimoto H, Hyodo S, Kawasaki M, Shibata M, Saito T, Suzuki H, Otsubo H, Yokoyama T, Fujihara H, Higuchi T, Takey Y and Ueta Y: Adrenomedullin 2 (AM2)/Intermedin is a more potent activator of hypothalamic ocytocin-secreting neurons than AM possibly through an unidentified receptor in rats. Peptides 28: 1104-1112, 2007.

10. Cui H, Kohsaka A, Waki H, Gouraud S, Nakamura T, Yukawa K, Hatada A, Bhuiyan MER and Maeda M: Adrenomedullin 2 microinjection into the nucleus tractus solitarius elevates arterial pressure and heart rate in rats. Auton Neurosci 142: 45-50, 2008.

11. Toda M, Suzuki T, Hosono K, Kurihara Y, Kurihara H, Hayashi I, Kitasato H, Hoka S and Majima M: Roles of calcitonin generelated peptide in facilitation of wound healing and angiogenesis. Biomed Pharmacother 62: 352-359, 2008.

12. Toda M, Suzuki T, Hosono K Hayashi I, Hashiba S, Onuma Y, Amano H, Kurihara Y, Kurihara H, Okamoto H, Hoka S and Majima M: Neural system-dependent facilitation of tumor angiogenesis and tumor growth by calcitonin gene-related peptide. Proc Natl Acad Sci USA 105: 13550-13555, 2008.

13. Ribatti D, Guidolin D, Conconi MT, Nico B, Baiguera S, Parnigotto PP and Vacca A: Vinblastine inhibits the angiogenic response induced by adrenomedullin in vitro and in vivo. Oncogene 22: 6458-6461, 2003.

14. Fernandez-Sauze S, Delfino C, Mabrouk K, Dussert C, Chinot O, Martin PM, Grisoli F, Ouafik L and Boudouresque F: Effects of adrenomedullin on endothelial cells in the multistep process of angiogenesis: involvement of CRLR/RAMP2 and CRLR/RAMP3 receptors. Int J Cancer 108: 797-804, 2004.

15. Guidolin D, Albertin G, Spinazzi R, Sorato E, Mascarin A, Cavallo D, Antonello M and Ribatti D: Adrenomedullin stimulates angiogenic response in cultured human vascular endothelial cells: involvement of the vascular endothelial growth factor receptor 2 . Peptides 29: 2013-2023, 2008.
16. Smith RS, Gao L, Bledsoe G, Chao L and Chao J: Intermedin is a new angiogenic growth factor. Am J Physiol Heart Circ Physiol 297: H1040-H1047, 2009.

17. Poyner DR, Sexton PM, Marshall J, Smith DM, Quiron R, Born W, Muff R, Fischer JA and Foord SM: International Union of Pharmacology. XXXII. 2002. The mammalian calcitonin gene-related peptides, adrenomedullin, amylin and calcitonin receptors. Pharmacol Rev 54: 233-246, 2002.

18. Lawley TJ and Kubota Y: Induction of morphologic differentiation of endothelial cells in culture. J Invest Dermatol 93: 598-618, 1989.

19. Arnaoutova I, George J, Kleinman HK and Benton G: The endothelial cell tube formation assay on basement membrane turns 20: state of the science and the art. Angiogenesis 12: 267-274, 2009.

20. Conconi MT, Lora S, Baiguera S, Boscolo E, Folin M, Scienza R, Rebuffat P, Parnigotto PP and Nussdorfer GG: In vitro culture of rat neuromicrovascular endothelial cells on polymeric scaffolds. J Biomed Mater Res A 71: 669-674, 2004.

21. Albertin G, Guidolin D, Sorato E, Spinazzi R, Mascarin A, Oselladore B, Montopoli M, Antonello M and Ribatti D: Proangiogenic activity of Urotensin-II on different human vascular endothelial cell populations. Regul Pept 157: 64-71, 2009.

22. Albertin G, Carraro G and Nussdorfer GG: Human adrenomedullin gene silencing by short interfering RNAs: a preliminary study. Int J Mol Med 15: 579-583, 2005.

23. Albertin G, Rucinski M, Carraro G, Forneris M, Andreis PG, Malendowicz LK and Nussdorfer GG: Adrenomedullin and vascular endothelium growth factor genes are overexpressed in the regenerating rat adrenal cortex and AM and VEGF reciprocally enhance their mRNA expression in cultured rat adrenocortical cells. Int J Mol Med 16: 431-435, 2005.

24. Pfaffl MW: A new mathematical model for relative quantification in real-time RT-PCR. Nucleic Acid Res 29: E45, 2001.

25. Pfaffl MW, Horgan GW and Dempfle L: Relative expression software tool $\left(\mathrm{REST}^{\circ}\right)$ for group-wise comparison and statistical analysis of relative expression results in real-time PCR. Nucleic Acid Res 30: E36, 2002.

26. Guidolin D, Vacca A, Nussdorfer GG and Ribatti D: A new image-analysis method based on topological and fractal parameters to evaluate the angiostatic activity of docetaxel by using the Matrigel assay in vitro. Microvasc Res 67: 117-124, 2004.

27. Eguchi S, Hirata Y, Iwasaki H, Sato K, Watanabe TX, Inui T, Nakajima K, Sakakibara S and Marumo F: Structure-activity relationship of adrenomedullin, a novel vasodilatory peptide, in cultured rat vascular smooth muscle cells. Endocrinology 135: 2454-2458, 1994.

28. Chiba T, Yamaguchi A, Yamatani T, Nakamura A, Morishita T, Inui T, Fukase M, Noda T and Fujita T: Calcitonin gene-related peptide receptor antagonist human CGRP-(8-37). Am J Physiol 256: E331-E335, 1989

29. Fong T, Shawver LK, Sun L, Tang C, App H, Powell TJ, Kim YH, Schreck R, Wang X, Risau W, Ullrich A, Hirth KP and McMahon G: SU5416 is a potent and selective inhibitor of the vascular endothelial growth factor receptor (Flk-1/KDR) that inhibits tyrosine kinase catalysis, tumor vascularization and growth of multiple tumor types. Cancer Res 59: 99-106, 1999.

30. Ribatti D, Conconi MT and Nussdorfer GG: Nonclassic endogenous novel regulators of angiogenesis. Pharmacol Rev 59: 185-205, 2007.

31. Dong YL, Reddy DM, Green RE, Chauhan MS, Wang HQ, Nagamani M, Hankins GD and Yallampalli C: Calcitonin generelated peptide (CALCA) is a proangiogenic growth factor in the human placental development. Biol Reprod 76: 892-899, 2007.

32. Lowes VL, Ip NY and Wong YH: Integration of signals from receptor tyrosine kinases and $\mathrm{G}$ protein-coupled receptors. Neurosignals 11: 5-19, 2002.

33. Linseman DA, Benjamin CW and Jones DA: Convergence of angiotensin II and platelet-derived growth factor receptor signaling cascades in vascular smooth muscle cells. J Biol Chem 270: 12563-12568, 1995.

34. Daub H, Weiss FU, Wallasch C and Ullrich A: Role of transactivation of the EGF receptor in signalling by $\mathrm{G}$ protein-coupled receptors. Nature 379: 557-560, 1996.

35. Rao GN, Delafontaine P and Runge MS: Thrombin stimulates phosphorilation of insulin-like growth factor-1 receptor, insulin receptor substrate-1 and phospholipase C-gamma 1 in rat aortic smooth muscle cells. J Biol Chem 270: 27871-27875, 1995. 